\title{
Vermicomposting Kitchen, Municipal Market and Tea Factory Waste using EiseniaFetida Earthworms
}

\author{
Mochache $\mathrm{M}^{1}$, Yegon $\mathrm{R}^{1 *}$, Ngetich $\mathrm{O}^{2}$ \\ ${ }^{1}$ Department of Land and Water Management, University of Embu, P.O Box 6-60100 Embu, Kenya \\ ${ }^{2}$ Department of Agricultural Resource Management, University of Embu, P.O Box 6-60100 Embu, Kenya \\ *Corresponding Author
}

\begin{abstract}
Population increase, urbanization, industrialization and agricultural activities result in accumulation of solid waste. This waste requires sustainable management through techniques such as vermicomposting. The study aimed at determining the rate of vermicomposting of kitchen, municipal market and tea factory waste using Eisenia fetida earthworm species at the University of Embu, Kenya. The study was arranged in completely randomized design replicated thrice. Data was collected on decomposition rate, carbondioxide evolution, earthworm count, nutrient content of vermicompostedwaste and days to vermicompost maturity. SAS version 9.4softwarewas used for statistical data analysis. Treatment means were separated using least significant difference (l.s.d.) at $p \leq 0.05$ probability level. Kitchen waste vermicompost had the fastest decomposition rate of 0.6 $\mathrm{kg} /$ day. Carbondioxide evolution analysis was done weekly whereby a value of $0 \mu g \mathrm{CO}_{2} / g$ vermicompost $/ \mathrm{m}^{2} /$ day was recorded at week 15 when the vermicomposts had stabilized. Kitchen and market waste vermicompostshad the highest earthworm countof 169 and 153, respectively.The nutrient contents of the three vermicomposts were not significantly different. The study concluded that kitchen waste had the highest vermicomposting rate as well as earthworm count. Therefore, the study recommends that kitchen waste and market waste can be used where the aim of vermicomposting is earthworm production.
\end{abstract}

Keywords- Nutrients, earthworms, decomposition, stability.

\section{INTRODUCTION}

Global waste production is predicted to increase from the current 2 billion tonnes per year to 3.4 billion tonnes in 2050 (Kazaet al., 2018). Embu municipality produces approximately 9,344 tonnes of waste per year, out of which only $15 \%$ is collected and transported to the dumpsite (Nicholas, 2013). The waste in Embu municipality was found to compose $53 \%$ organic/biodegradable waste (Nicholas, 2013).This necessitates adoption of technologies to manage these wastes. Vermicomposting refers to the use of earthworms to convert biodegradable waste into high quality manure (Parekh and Mehta, 2015).Vermicompostprovides macro and micro-nutrients to plants.

Vermicomposted urban green waste has been found to contain: $\quad 2.0-3.0 \%$ Nitrogen $(\mathrm{N}), \quad 16000-23000 \mathrm{mg} / \mathrm{kg}$ Phosphorus (P), and 19000-26000 mg/kgPotassium (K) (Sinha et al., 2009). In Malaysia, vermicomposted wastes were found to contain $0.87 \%$ to $1.9 \% \mathrm{~N}, 2300-4600$ $\mathrm{mg} / \mathrm{kg} \mathrm{P}, 4000-27400 \mathrm{mg} / \mathrm{kg} \mathrm{K}$ and $168800-321400 \mathrm{mg} / \mathrm{kg}$ C (Jamaludin\&Mahmood, 2008). In Kenya, manure basedvermicompost was found to contain $1.9 \% \mathrm{~N}, 3000 \mathrm{mg} / \mathrm{kg} \mathrm{P}$ and $27000 \mathrm{mg} / \mathrm{kg} \mathrm{K}$ (Savala, 2007). However, the nutrient content depends on the quality of organic waste(Kumar $e t$ al., 2018). Vermicompost takes about two months to mature, for instance, that of agricultural waste (Nagavallemaet al., 2004).Vermicompost is applied to high value crops as a source of plant nutrients. For instance, agro-based waste vermicompost has been utilized for greenhouse kale productionin the Central highlands of Kenya (Karuku et al., 2016).

Vermicomposting is solid waste management technique which converts organic wastes into organic fertilizer (Rosmanet al., 2017).Vermicomposting is thus efficient environmentally, economically and socially, making it a global waste reduction technique (Parekh \& Mehta, 2015).Suitable earthworm species for vermicomposting include: Eisenia Andrei, Eiseniafetida and Lumbricusrubellis (Dominguez \& Edwards, 2010).The vermicomposting earthworms are characterized by high 
organic matter consumption rates, high reproduction rates, high environmental stress tolerance, rapid hatching, growthand maturation(Malińskaet al., 2017).

Tea is the major cash crop in Kenya, contributingabout $11 \%$ economic growth in the agricultural sector and supportingapproximately 5 million livelihoods (Kaiyaga, 2015). Tea waste produced in Rukuriri Tea factory totals to 9.125 tonnes a year (Rukuriri Factory Tea Waste Records, 2018). This waste is a potentially valuable resource that can be utilized for preparation of vermicompost, a soil amendment.Organic wastes generated during tea processing include refuse tea, shade tree lopping's, tea pruning's and weeds (Hitinayake et al., 2018). Green tea leaves were used for vermicomposting in the study.The University of Embu Kitchen generates 365 tonnes of waste annually (Mochache, 2016). This is a big resource that can be vermicomposted to supply nutrients for sustainable crop production.Embu town $\begin{array}{lll}\text { market } & \text { generates approximately } & 2.6\end{array}$ tonneswasteannually(Environment and Natural Resource Department, Embu County Government, 2017).The 53\% organic waste generated in Embu town market can be transformed into vermicompost for increasing crop productivity.

The basis of formulating this study was to prepare and analyze vermicompost from three organic wastes: kitchen waste, municipal market waste and tea factory waste. The study therefore aims at determining the rate of vermicomposting of kitchen, market and tea factory wastes using Eisenia fetida earthworm species.

\section{MATERIALS AND METHODS}

\section{Study Area}

The study site was the University of Embu, Embu County, Kenya. The site is located $3 \mathrm{~km}$ from Embu Town along the Embu-Meru highway. The site lies at an elevation of 1, 350 metres (Kenya Information Guide, 2015). Embu has a bimodal rainfall pattern receiving long rains between March and June and short rains between October and December (Embu County Government, 2013).The University of Embu receives an average annual rainfall of $1232 \mathrm{~mm}$ and has a mean annual temperature of $18.7{ }^{\circ} \mathrm{C}$ (Jaetzoldet al., 2006).HumicNitisolswith moderate to high fertility characterize the study site(Verde et al., 2013).

\section{Vermicompost preparation}

Each vermicompost type was prepared in three plastic 120 litres capacity bins.Kitchen waste was obtained from the University of Embu kitchen, market wastefrom Embu Town Market and tea waste from Rukuriri Tea Factory in Embu.
Earthworms were obtained from a commercial worm grower in Juja, Kenya and transported in a bucket containing worm casts and organic residues on top as earthworm feed.The experiment was conducted at room temperaturein a dark room. $100 \mathrm{~g}$ banana leaves were placed as the worm bedding, 2.5 kilograms(1250 earthworms) placed on the bedding, followed by $2 \mathrm{~kg}$ cattle manure then $1 \mathrm{~kg}$ of waste (from the kitchen, market and tea factory). A three months pre-composting was done to preserve worm mortality and ensure multiplication. Vermicomposted kitchen waste comprised carrots peelings and cabbage and kales leaves. Vermicomposted market waste comprised banana, potato and fruit peelings. Vermicomposted tea waste comprised the green leaves. A cover of $100 \mathrm{gdry}$ banana leaves was added at the top. The vermicompost was kept at $60-70 \%$ moisture content by adding a litre of water once per week. The duration of the experiment was seventeen weeks for the first season and fifteen weeks for the second season.This was because in both seasons, stabilization took place by the fifteenth week whereby no further carbondioxide evolution was observed.

\section{Study Design}

The study was carried out for two seasons, July 2018 and November 2018 for the first season and November2018 and February 2019 for the second season. The vermicomposting vessels were arranged in completely randomized design replicated three times. The treatments were: vermicomposted kitchen waste, vermicomposted market waste and vermicomposted tea factory waste.

\section{Data Collection}

Data collection was done on carbon dioxide evolution, earthworm count, decomposition rate and days to vermicompost maturity and nutrient content (N (\%), $\mathrm{P}(\mathrm{mg} / \mathrm{kg}), \mathrm{K}(\mathrm{mg} / \mathrm{kg})$ and $\mathrm{C} \%)$ of the three vermicomposts.

\section{Carbondi oxide Evolution}

Carbon dioxide evolution ( $\mu \mathrm{gCO}_{2} / \mathrm{g}$ vermicompost $/ \mathrm{m}^{2} /$ day) was done weekly(as from the second week of the setup) following the procedure modifiedby Strotmann et al. (2004). Sodium hydroxide $(20 \mathrm{ml})$ was placed in a vial which was suspended on the vermicomposting bin to collect carbondioxide overnight for a period of 24 hours and afterwards analyzed by titrating with Hydrochloric acid (1M) to obtain the carbon dioxide evolved from the experiment.

\section{Farthworm Count}

Earthworm sampling was done weekly on the different vermicomposts using the method ofBouché and Gardner 
(1984). This was done by isolating, hand sorting and physical counting of the earthworms to determine their numbers once per week.

\section{Nutrient Analysis}

Nitrogen (\%), Phosphorus (mg/kg), Potassium (mg/kg) and Carbon $(\mathrm{mg} / \mathrm{kg})$ were determined in the vermicomposts. Total nitrogen was analyzedfollowing the procedure of Page et al. (1982).The elements $\mathrm{P}$ and $\mathrm{K}$ were analysed following the procedures of Mehlichet al. (1962). Potassium was determined with a flame photometer and Phosphorus spectrophotometrically. Total organic carbon (TOC) analys is was analysedfollowing the procedure of Anderson \& Ingram (1993).

\section{Decomposition Rate}

Decomposition rate was determined using the equation of (Rovira\&Rovira, 2010):

$-\mathrm{k}=\mathrm{dX} / \mathrm{dt} \mathrm{X}$, where- $\mathrm{k} \quad$-decomposition rate constant, $\mathrm{dX}$ -change in initial litter mass, dt -change in

time and $\mathrm{X} \quad$-initial litter mass

Data Analysis

SAS software version 9.4 was used for statistical data analysis (SAS, 2013). Data was subjected to two-way analysis of variance using SAS GLM code of the model $\mathrm{CRD}$, to determine the difference inearthworm count and carbondioxideevolution at the beginning and end of the study. Statistically $\quad \operatorname{significant}(\mathrm{p} \leq 0.05)$ treatments meanswere separated using l.s.d.

\section{RESULTS AND DISCUSSION}

\section{Vermicomposting rate of the wastes}

Maturity indicates suitability of vermicompost for plant growth (Majlessiet al., 2012).The vermicompost from the three organic wastes took 107 days to maturein the first season. In the second season, the three vermicomposts took 98 days for kitchen waste, 105 days for market and tea waste to reach maturity; this was because of the differences in the C: $\mathrm{N}$ ratio of the materials. Nurhidayati (2018) reported that compost reached maturity when the $\mathrm{C}$ : $\mathrm{N}$ ratio was $<20$. According to Alidadi et al. (2016) the adequate time for municipal solid waste vermicompost maturation was reported to be 75 days. Similarly, Aynehbandet al. (2017) vermicomposted cereal wastes in 90 days, whereas Gopal et al. (2018) vermicomposted coconut wastes for 80 days. The differences in the vermicomposting rates in the different studies may be related to temperature differences. The higher the environmental temperatures the higher the decomposition rates consequently the faster the maturity.
In the first season kitchen waste was found to have the highest decomposition rate at $0.51 \mathrm{~kg} / \mathrm{day}$, tea waste followed at $0.48 \mathrm{~kg} /$ day and market waste had the lowest decomposition rate at $0.45 \mathrm{~kg} / \mathrm{day}$. In the second season kitchen waste still maintained a higher decomposition rate at $0.6 \mathrm{~kg} /$ day as compared to tea waste $0.54 \mathrm{~kg} /$ day and market waste $0.53 \mathrm{~kg} /$ day. The different vermicomposting rates of the residues may be related to residue quality as suggested by Aynehbandet al. (2017).Wardle et al.(2009) and Moore et al.(2011)found that chemical composition differences in residues such as, lignin content, organic Carbon content, $\mathrm{C}$ : $\mathrm{N}$ ratio and lignin affected decomposition rates.Residues with a high C: Nratios have slower decomposition rates and those with high $\mathrm{N}$ content have high rates of decomposition (Ali,2011).

\section{Earthworm Count}

Earthworms multiply under suitable ecological conditions as well as suitable food, temperature and oxygen (Chanda et $a l ., 2013)$. In season one, kitchen waste had a significantly higher $(\mathrm{p} \leq 0.05)$ earthworm count of 572earthworms per kilogram of vermicompost compared to market waste vermicompost at 364earthworms and tea waste vermicompost at 352earthworms at the end of the study. In the second season, significant differences $(\mathrm{p} \leq 0.05)$ were also observed at the end of the study, whereby kitchen and market waste vermicomposts had a significantly higher $(p \leq 0.05)$ earthworm count of 676 and 612 earthworms respectively, per kilogram of vermicompost, compared to tea waste vermicompost at 432 earthworms.

In both seasons of the present study the initial number of earthworms was low but at the end of the study the number of earthworms had increased by over $50 \%$ for each type of vermicompost.In season one;tea waste recorded the highest earthworm increase at $283 \%$, followed by kitchen waste at $211 \%$ and market waste followed at $63 \%$. In season two, kitchen waste vermicompost recorded the highest increase in earthworm count at $273 \%$, followed by market waste vermicompost at $248 \%$ increaseand tea waste vermicompost at $212 \%$. High numbers of earthworms were recorded in kitchen waste as it is a rich inorganic feeding material ideal for earthworm growth and reproduction (Albasha, 2015). This corresponds to the findings of Lalanderet al.(2015), who foundan increase of $65 \%$,Abu Bakar et al. (2014)who found a $92 \%$ increase,Mathivananet al., (2017)who found a 77 - 94\% increase andGopal et al. (2018) who found a 300 fold increase in earthworm numbers on vermicomposting. The results of the present study indicating differences in earthworm numbers based on the type of 
residue agree with those of Aynehbandet al. (2017) who using different wastes.

found differences in earthworm number and activity on

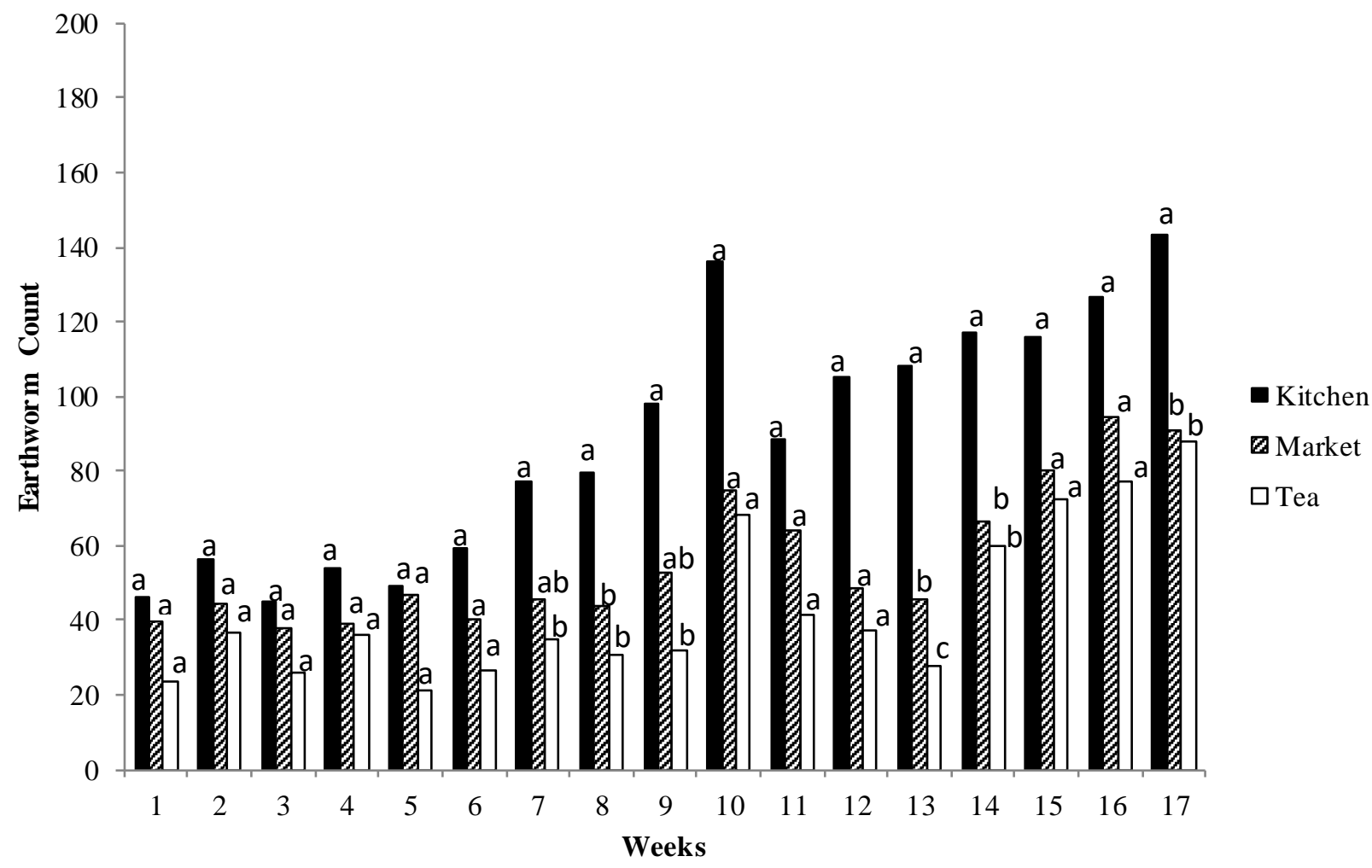

Fig.1: Season 1 Earthworm Count

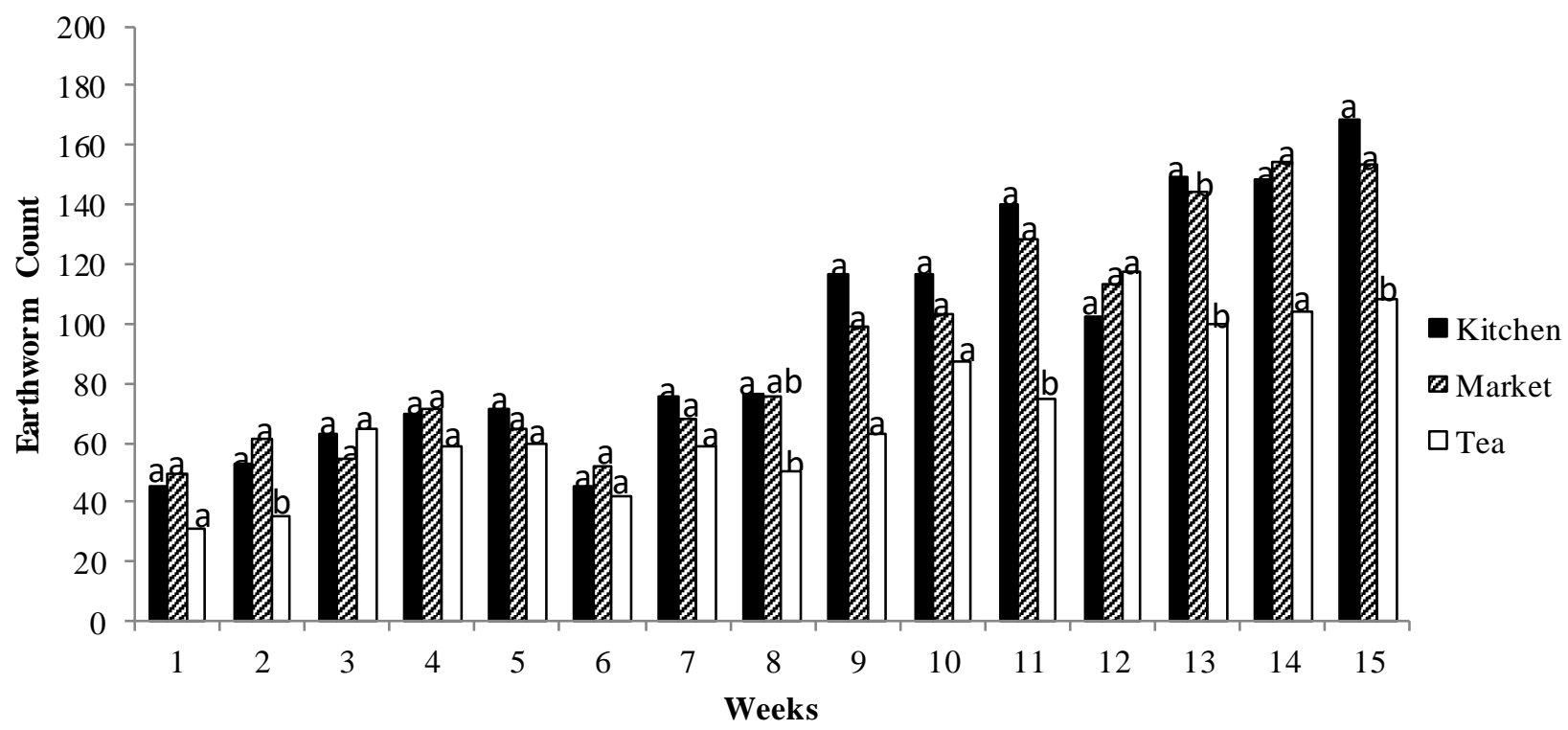

Fig.2: Season 2 Earthworm Count

Carbon Dioxide Evolution 
In the first season, there was no significant difference in carbondioxide evolution by the seventeenth week $(\mathrm{p} \geq 0.05)$. However, significant differences $(\mathrm{p} \geq 0.05)$ were observed in weeks 1 and 11, whereby in week 1 , tea wastevermicompost had a significantly higher carbondioxide evolution (12767 $\mu \mathrm{gCO}_{2} / \mathrm{g}$ vermicompost $/ \mathrm{m}^{2} /$ day ) compared to kitchen waste vermicompostat $5133 \mu \mathrm{gCO}_{2} / \mathrm{g}$ vermicompost $/ \mathrm{m}^{2} /$ day and market waste vermicompost at $2033 \mu \mathrm{gCO}_{2} / \mathrm{g}$ vermicompost $/ \mathrm{m}^{2} /$ day. In week 11 , market waste vermicompost had a significantly higher carbondioxide evolution of 5668 compared to kitchen waste vermicompost at $800 \mu \mathrm{gCO}_{2} / \mathrm{g}$ vermicompost $/ \mathrm{m}^{2} /$ day and tea waste vermicompost at $0 \mu \mathrm{gCO} / \mathrm{g}$ vermicompost $/ \mathrm{m}^{2} / \mathrm{day}$. By the end of the second season, there was no significant difference in the carbondioxide evolution of the treatments $(\mathrm{p} \leq 0.05)$. In the second season, significant differences in the carbondioxide evolution were observed in weeks 1 and 5, whereby kitchen waste vermicompost had a significantly higher carbondioxide evolution at $14567 \mu \mathrm{gCO}_{2} / \mathrm{g}$ vermicompost $/ \mathrm{m}^{2} /$ day and $10967 \mu \mathrm{gCO}_{2} / \mathrm{g}$ vermicompost $/ \mathrm{m}^{2} /$ day $(\mathrm{p} \geq 0.05)$ compared to market and tea

$\begin{array}{lllr}\text { waste vermicomposts at } & & 10500 \mu \mathrm{gCO}_{2} / \mathrm{g} \\ \text { vermicompost } / \mathrm{m}^{2} / \text { day } & \text { and } & 8833 & \mathrm{\mu CO}_{2} / \mathrm{g}\end{array}$
vermicompost $/ \mathrm{m}^{2} /$ day respectively. The three vermicompost types stabilized at week 15 whereby a value of $0 \mu \mathrm{gCO}_{2} / \mathrm{g}$ vermicompost $/ \mathrm{m}^{2} /$ day was recorded (Figure 3, 4).

This was done to indicate vermicompost stability. In both seasons as indicated by Figures 3 and 4, high values of carbondioxide evolution were observed among the kitchen, municipal market and tea vermicompost at the beginning of the experiment, but values gradually reduced until they were constant towards the end of the experiment, thus indicating that vermicompost had stabilized. This corresponded to the findings of Nayak et al.(2013) whereby lower values of carbondioxide evolution indicated more vermicompost stabilization. Increased carbondioxide evolution rates indicated higher earthworm and microbial respiration rate as well as aerobic biological activity (Kalamdhadet al., 2008; Sonawane, 2016). Lower carbondioxide evolution values were as a result of reduced metabolic activity which results in decreased respiration rate of microbes and earthworms (Nayak et al., 2013).

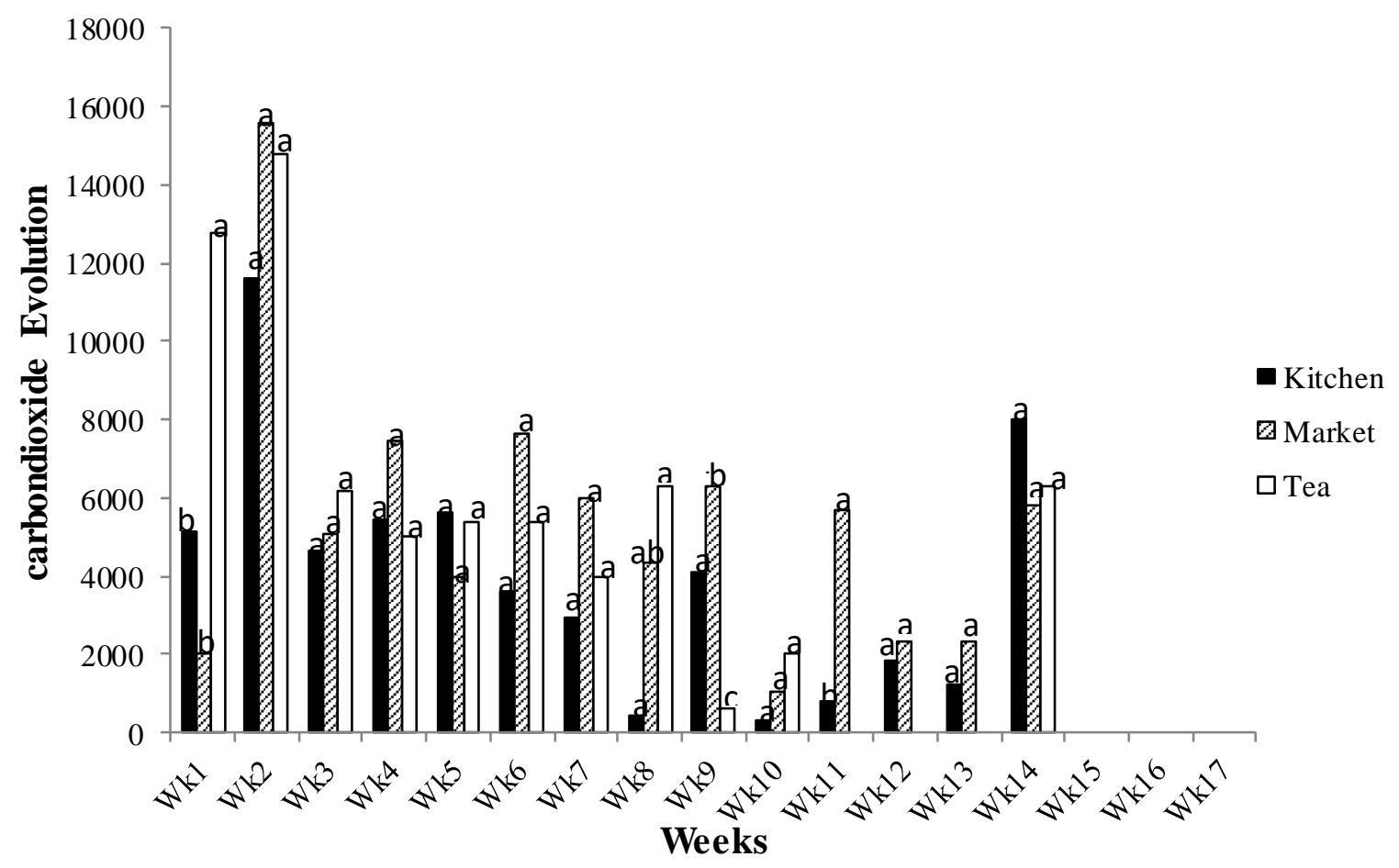

Fig.3: Season 1 Carbondioxide Evolution 


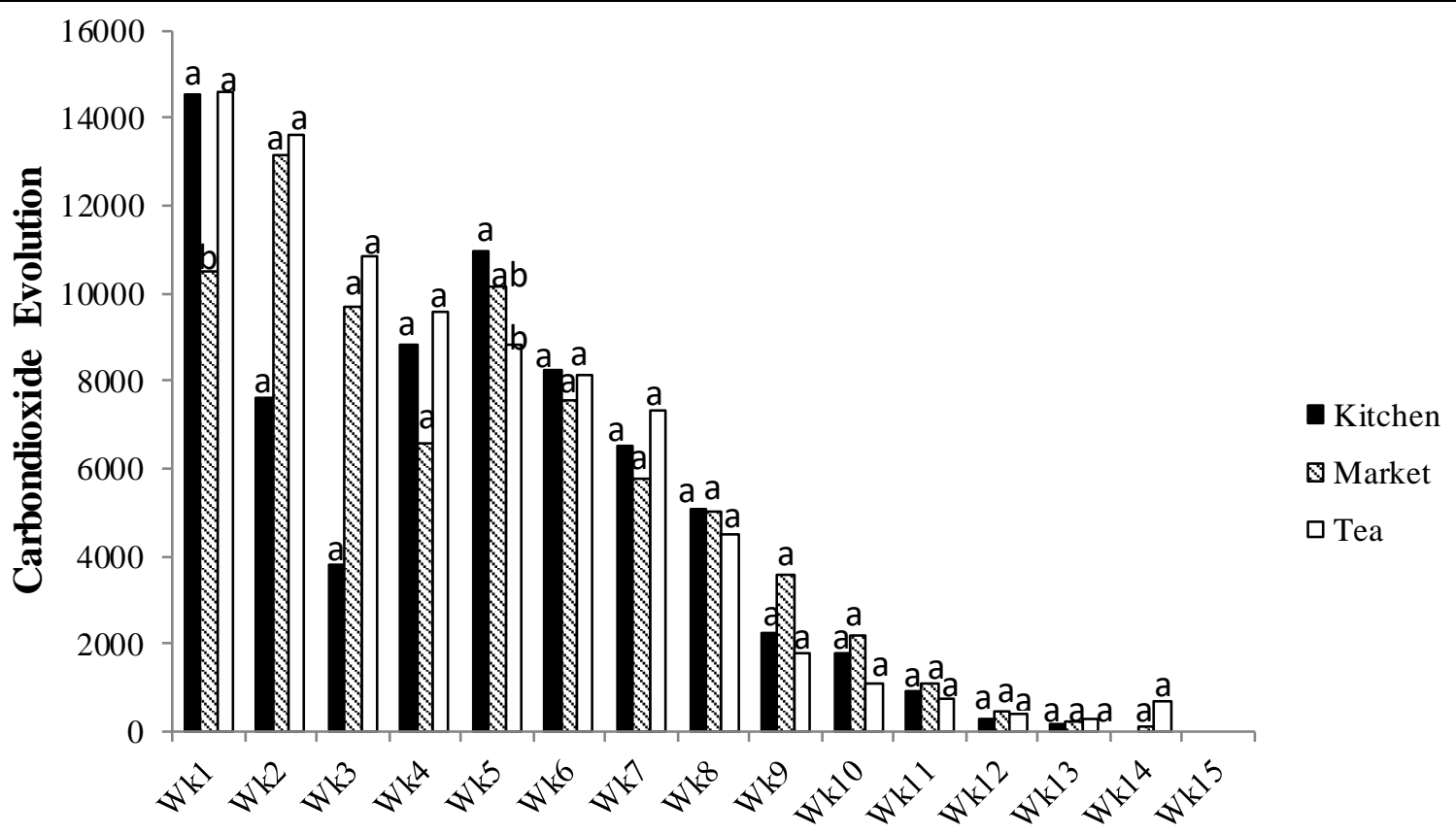

Weeks

\section{Vermicompost Nutrient Analysis}

Fig.4: Season 2 Carbondioxide Evolution

Table 1 indicates the statistical analyses of the nutrient content of the vermicomposts.

Table 1 Vermicompost nutrient content

\begin{tabular}{lllll}
\hline Treatment & Nitrogen $(\%)$ & Phosphorus $(\mathbf{m g} / \mathbf{K g})$ & $\begin{array}{l}\text { Potassium } \\
(\mathbf{m g} / \mathbf{K g})\end{array}$ & $\begin{array}{l}\text { Organic Carbon } \\
(\mathbf{m g} / \mathbf{k g})\end{array}$ \\
\hline Kitchen & $0.5067^{\mathrm{a}}$ & $8067^{\mathrm{a}}$ & $27433^{\mathrm{a}}$ & $150000^{\mathrm{a}}$ \\
Market & $0.8167^{\mathrm{a}}$ & $7667^{\mathrm{a}}$ & $19700^{\mathrm{a}}$ & $153330^{\mathrm{a}}$ \\
Tea & $0.7767^{\mathrm{a}}$ & $7600^{\mathrm{a}}$ & $24167^{\mathrm{a}}$ & $150670^{\mathrm{a}}$ \\
P-value & 0.1066 & 0.9354 & 0.1382 & 0.9499 \\
1.s.d & 0.3199 & 0.3362 & 0.8025 & 2.5525 \\
\hline
\end{tabular}

Though the nutrient contents were statistically similar ( $\mathrm{p} \geq 0.05$ )among the treatments, (Table 1), $\mathrm{N}$ content was higher in market waste than tea and kitchen waste vermicomposts by $5.1 \%$ and $64 \%$ respectively. Phosphorus content was higher inkitchen waste vermicompost than market and tea waste vermicomposts by $5.2 \%$ and $6.1 \%$ respectively. Kitchen waste vermicompost had the higherK content than tea and market waste vermicomposts by $13.5 \%$ and $39.3 \%$ respectively. Organic carbon content was higher in market waste vermicompost than tea and kitchen waste vermicomposts by $1.8 \%$ and $2.22 \%$ respectively.

An et al. (2014)found vermicomposted kitchen waste (food scraps) containing $0.5 \%$ available $\mathrm{N}, 2400 \mathrm{mg} / \mathrm{kg}$ available $\mathrm{P}, \quad 3000 \mathrm{mg} / \mathrm{kg}$ available $\mathrm{K}, 0.6 \% \mathrm{Mg}$ and $0.2 \% \mathrm{Ca}$. Additionally, Wani and Rao, (2013) found vermicomposted tea waste containing an organic carbon content of 133,000 $\mathrm{mg} / \mathrm{kg}$. The results of the present study on the $\mathrm{N}$ content of kitchen wastes agree with those of An et al. (2014).The higher $\mathrm{P}$ and $\mathrm{K}$ contents in the present study may be due to the quality of the kitchen wastes used. The nutrient content of municipal solid waste was found by Pattnaik and Reddy (2009) to be $0.5 \% \mathrm{~N}, 3000 \mathrm{mg} / \mathrm{kg} \mathrm{P}, 2000 \mathrm{mg} / \mathrm{kg} \mathrm{K}$ and 796 $000 \mathrm{mg} / \mathrm{kg}$ organic C.The $\mathrm{N}, \mathrm{P}, \mathrm{K}$ contents of the present study are much higher than those of Pattnaik and Reddy (2009). This could be due to differences in the quality of the market residues in the present study. Vermicomposted tea waste is reported to contain $0.9 \% \mathrm{~N}, 6000 \mathrm{mg} / \mathrm{kg} \mathrm{P}$, $51000 \mathrm{mg} / \mathrm{kg} \mathrm{K}$, and $259000 \mathrm{mg} / \mathrm{kg} \mathrm{C}$ (Abbiramyet al., 2015). The tea waste vermicompost $\mathrm{N}$ and $\mathrm{P}$ contents in the present study are similar to those of (Abbiramy et al., 
2015)but the $\mathrm{K}$ contents are lower. This may be due to differences in the quality of the leaves.

\section{CONCLUSION}

The study determined the decomposition rates of vermicomposted kitchen, municipal and tea factory waste. Kitchen waste had a higher vermicomposting rate compared to tea and market waste. Kitchen waste and market waste vermicomposts had higher earthworm count compared to tea waste vermicompost. Stability of the vermicomposted waste was determined by carrying out carbondioxide evolution, whereby low carbondioxide evolved indicated stability of the vermicompost. Kitchen wastes and market wastes can be used to rear earthworms for use in vermicomposting or livestock feed. This study therefore recommends kitchen and market wastes where the aim of vermicomposting is earthworm production.Market, kitchen and tea waste can be used as soil amendments as they have statistically similar nutrient contents $(\mathrm{p} \geq 0.05)$.

\section{ACKNOWLEDGEMENT}

University of Embu and Rukuriri Tea Factory.

\section{REFERENCES}

[1] Abbiramy, K., Ross, P. R., \& Paramanandham, J. (2015). Degradation of Tea Factory Waste by Mushroom Cultivation and Vermicomposting. Journal of Environmental Science \& Engineering. Vol, 57(2), 126-130.

[2] Abu Bakar, A., Syed Mohd Gawi, S., Mahmood, N. Z., \& Abdullah, N. (2014). Vermicomposting of vegetable waste amended with different sources of agro-industrial by-product using Lumbricus rubellus. Polish Journal of Environmental Studies, 23(5), 14911498.

[3] Albasha, M. O., Gupta, P., \& Ramteke, P. (2015). Management of kichen waste by vermicomposting using earthworm, Eudrilus eugeniae. Paper presented at the International Conference Advantages in Agricultural, Biological and Environmental Sciences, July 22-23, 2015 London, UK, 81-84.

[4] Ali, S.H.N. (2011). Effect of Composted and Vermicomposted Cotton Residues on Nutrient Contents, Ryegrass Growth and Bacterial Blight Mitigation. A Dissertation (Doctor of Philosophy) presented to the Faculty of Agricultural Sciences of the Georg-August-University Göttingen, Germany, 1209.
[5] Alidadi, H., Hosseinzadeh, A., Najafpoor, A. A., Esmaili, H., Zanganeh, J., Takabi, M. D., \& Piranloo, F. G. (2016). Waste recycling by vermicomposting: Maturity and quality assessment via dehydrogenase enzyme activity, lignin, water soluble carbon, nitrogen, phosphorous and other indicators. Journal of environmental management, 182, 134-140.

[6] An, Y., Wu, W., He, W., Xu, J., Chen, J., \& Li, G. (2014). Study on Kitchen Waste Characteristics of Different Catering Types in Shanghai. In: Advanced Materials Research, 878, 427-432. Trans Tech Publications.

[7] Anderson, J.M. and J.S.I. Ingram. (1993). Tropical Soil Biology and Fertility: A Handbook of Methods. CAB International, Wallingford, Oxon, UK.

[8] Aynehband, A., Gorooei, A., \& Moezzi, A. A. (2017). Vermicompost: An Eco-Friendly Technology for Crop Residue Management in Organic Agriculture. Energy Procedia, 141, 667-671.

[9] Bouché, M., \& Gardner, R. (1984). Earthworm functions. VIII: Population estimation techniques. Revue d'Ecologie et de Biologie du Sol, 21(1), 37-63.

[10] Chanda, G., Bhunia, G., \& Chakraborty, S. (2013). Assessment of decomposition rate and recovery number of earthworm Perionyx excavatus perrier during vermicomposting by combined index (CBI). Global Advanced Research Journal of Environmental Science and Toxicology, 2(8), 183-187.

[11] Dominguez, J., \& Edwards, C. A. (2010). Biology and ecology of earthworm species used for vermicomposting. Vermiculture Technology: Earthworms, Organic Waste and Environmental Management, 25-37.

[12] Embu County Government (2013). County Integrated Development Plan 2013-2017. http://www.embu.go.ke/wpcontent/uploads/2016/09/embu-county-draft-cidp.pdf Accessed 14/11/18

[13] Environment and Natural Resource Department, Embu County Goverment (2017). Embu town market waste records. Accessed 27/03/2018.

[14] Gopal, M., Gupta, A and Chowdappa, P. (2018). Value addition to recalcitrant and voluminous palm biomass residues through vermicomposting technology. International Journal of Innovative Horticulture, 7(2), 63-70.

[15] Hitinayake, HMGSB, H., Ubayapala, K. G. K. C., Samaranayake, J. K. S., \& Weerasekera, W. A. T. H. 
(2018). Evaluation of Earthworm Species and Bedding Material Collected from Tea Plantations for Vermicomposting in Sri Lanka. International Journal of Environment, Agriculture and Biotechnology, 3(5), 1935-1939.

[16] Jaetzold, R., Schmidt, H., Hornetz, B., Shis anya, C.A., (2006). Farm Management Handbook of Kenya. Natural Conditions and Farm Information, 2nd edition, vol. 11/C. Ministry of Agriculture/GTZ, Nairobi, Kenya (Eastern Province). http://library.wur.n1/isric/fulltext/isricu_i00023897_00 1.pdf Accessed 14/11/2018

[17] Jamaludin, A. A., \& Mahmood, N. Z. (2008). Effect of post composting on vermicompost of spent mushroom substrate. Proceedings of the $10^{\text {th }}$ MSAB Symposium, Kuching 2008 Kuala Lampur, Malaysia, 5-8.

[18] Kaiyaga, M.K. (2015). Tea Supply Response in Kenya, 1990 - 2014. Research Paper Submitted to the school of Economics, University of Nairobi, in Partial Fulfillment of the Requirements for the Award of the Degree of Master of Arts in Economics, 1-56.

[19] Kalamdhad, A. S., Pasha, M., \& Kazmi, A. (2008). Stability evaluation of compost by respiration techniques in a rotary drum composter. Resources, Conservation and Recycling, 52(5), 829-834.

[20] Karuku, G. N., Kimenju, J. W., \& Verplancke, H. (2016). Farmers' perspectives on factors limiting tomato production and yields in Kabete, Kiambu County, Kenya. East African Agricultural and Forestry Journal, 82(1), 70-89.

[21] Kaza, S.; Yao, L, C., Bhada-Tata, P., Van Woerden, F. (2018). What a Waste 2.0 : A Global Snapshot of Solid Waste Management to 2050. Urban Development;. Washington, DC: World Bank. (C) World

Bank. https://openknowledge.worldbank.org/handle/10986/3 0317 License: CC BY 3.0 IGO."

[22] Kenya Information Guide (2015). Embu CountyKenya. http://www.kenya-informationguide.com/embu-county.html Accessed 14/11/18

[23] Kumar, A., Prakash, B., Brar, N. S., \& Kumar, B. (2018). Potential of Vermicompost for Sustainable Crop Production and Soil Health Improvement in Different Cropping Systems. International Journal of Microbiology and Applied Sciences, 7(10), 1042-1055.

[24] Lalander, C. H., Komakech, A. J., \& Vinnerås, B. (2015). Vermicomposting as manure management strategy for urban small-holder animal farms-Kampala case study. Waste management, 39, 96-103.

[25] Majlessi, M., Eslami, A., Saleh, H. N., Mirshafieean, S., \& Babaii, S. (2012). Vermicomposting of food waste: assessing the stability and maturity. Iranian journal of environmental health science \& engineering, 9(1), 25.

[26] Malińska, K., Golańska, M., Caceres, R., Rorat, A., Weisser, P., \& Ślęzak, E. (2017). Biochar amendment for integrated composting and vermicomposting of sewage sludge-The effect of biochar on the activity of Eisenia fetida and the obtained vermicompost. Bioresource technology, 225, 206-214.

[27] Mathivanan, M., Saravanan, G. A. V., \& Baji, A. (2017). Biodegradation of paper waste using Eisenia foetida by vermicomposting Technology. Paper presented at the IOP Conference Series: Earth and Environmental Science.

[28] Mehlich, A., Pinkerton, A., Robertson, W. and Kepton, R. (1962). Mass analysis methods for soil fertility evaluation. Cyclostyled Paper, National Agric. Laboratories, Nairobi.

[29] Mochache, M. (2016). Investigating Waste Management Techniques in Embu Unversity College. Project Report. Department of Land and Water Mangement. Embu University College , 1-43.

[30] Moore T. R, Trofymow J. A, Prescott C. E, Titus B. D. (2011). Nature and nurture in the dynamics of $C, N$ and $\mathrm{P}$ during litter decomposition in Canadian forest. Plant and Soil 339 (1), 163-175.

[31] Nagavallemma, K., Wani, S., Lacroix, S., Padmaja, V., Vineela, C., Rao, M. B., \& Sahrawat, K. (2004). Vermicomposting: Recycling Wastes into Valuable Organic Fertilizer. Global Theme on Agroecosystems Report no. 8.

[32] Nayak, A. K., Dhamodharan, K., \& Kalamdhad, A. S. (2013). Stability and Kinetic Analysis during Vermicomposting of Sewage Sludge. World Academy of Science, Engineering and Technology, International Journal of Environmental, Chemical, Ecological, Geological and Geophysical Engineering, 7(10), 707-715.

[33] Nicholas, M. G. (2013). Strategy for Solid Waste Management for the Municipal Council of Embu.

file://C:/Users/user/Downloads/Muchiri_.Strategy\%2 Ofor $\% 20$ Solid $\% 20 \mathrm{~W}$ aste $\% 20$ Management $\% 20$ for $\% 20$ 
the $\% 20$ Municipal\%20Council\%20of\%20Embu $\% 20$

(1).pdf Accessed 16/4/2019.

[34] Nurhidayati, N., Machfudz, M., \& Murwani, I. (2018). Direct and residual effect of various vermicompost on soil nutrient and nutrient uptake dynamics and productivity of four mustard Pak-Coi (Brassica rapa L.) sequences in organic farming system. International Journal of Recycling of Organic Waste in Agriculture,7(2), 173-181.

[35] Page, A. L., Miller, R. H. and Keeney, D. R. (eds.) (1982). Methods of soil analysis. Part 2. Second edition. Amer. Soc. of Agron., Madison, Winconsin, USA, 595-622.

[36] Parekh, S. A., \& Mehta, M. J. (2015). Vermicomposting as Sustainable Option for Organic Waste Management. International Journal of Innovative and Emerging Research in Engineering, 2(1), 13-20.

[37] Pattnaik, S., \& Reddy, M. V. (2009). Nutrient Status of Vermicompost of Urban Green Waste Processed by Three Earthworm Species-Eisenia fetida, Eudrilus eugeniae, and Perionyx excavatus. Applied and Environmental Soil Science,1-13.

[38] Rosman, P. S., Mohamad, M., Elangovan, T., Hasmi, N. A., Norzehan, E., Mahbob, M., \& Anuar, W. N. H. W. (2017). Vermicomposting using different substrates of spent tea waste: wood powder and orange peel powder as a potential electric generation. Paper presented at the Symposium on Innovation and Creativity (iMIT-SIC).

[39] Rovira, P., \& Rovira, R. (2010). Fitting litter decomposition datasets to mathematical curves: towards a generalised exponential approach. Geoderma, 155(3-4), 329-343.

[40] Rukuriri Factory Tea Waste Records, 2018 (2018). Quantity of Generated Tea waste in Rukuriri Tea Factory.

[41] SAS. (2013). Statistical Analysis System Release 9.4 SAS Institute, Cary.

http://www.sas.com/en_us/software/analytics/stat.html

[42] Savala, E.N.C. (2007). Chapter 11: Using earthworms to make vermicompost. https://infonetbiovision.org/res/res/files/4096.Vermicompost\%20ken ya.pdf Accessed 16/4/2018

[43] Sinha, R., Herat, S., Chauhan, K., \& Valani, D. (2009). Special Issue: Vermiculture \& sustainable agriculture. American-Eurasian Journal of Agricultural and Environmental Science, 5(S), 14-22.

[44] Sonawane, P. H. (2016). Changes in chemical properties during vermicomposting of organic residues as influenced by earthworm activity. Thesis (Master of Science) presented to the, Department of Soil Science and Agricultural Chemistry, Vasantrao Naik Marathwada Krishi Vidyapeeth, Parbhani, India 1-136.

[45] Strotmann, U., Reuschenbach, P., Schwarz, H., \& Pagga, U. (2004). Development and evaluation of an online $\mathrm{CO} 2$ evolution test and a multicomponent biodegradation test system. Applied and environmental microbiology, 70(8), 4621-4628.

[46] Verde, B. S., Danga, B. O., \& Mugwe, J. N. (2013). Effects of manure, lime and mineral $\mathrm{P}$ fertilizer on soybean yields and soil fertility in a humic nitisol in the Central Highlands of Kenya. International journal of Agricultural science research, 2(9), 283-291.

[47] Wardle DA, Bardgett RD, Walker LR, Bonner KI (2009) Among- and within-species variation in plant litter decomposition in contrasting long-term chronosequences. Functional Ecology 23, 442-453.

[48] Wani, K., \& Rao, R. (2013). Bioconversion of garden waste, kitchen waste and cow dung into value-added products using earthworm Eisenia fetida. Saudi Journal of Biological Sciences, 20(2), 149-154. 